доц. др Алексеј Тимофејев

316.722(497.11:47) Универзитет у Београду https://doi.org/10.18485/ai_most.2017.ch21 Филозофски факултет

Институт за новију историју Србије al.timofev@gmail.com

\title{
МОСТОВИ БЕОГРАДА У КОНТЕКСТУ СРПСКО-РУСКИХ ОДНОСА У 20. ВЕКУ
}

\begin{abstract}
Главни град Србије има више мостова изграђених махом у 20 веку. Мостове у Београду су градили и рушили највише сами Срби, али и бројни странци Немци, Данци, Французи, Кинези па и Руси. Најактивнији односи уз масовне контакте српског и руског народа одвијали су се када су Руси и Срби живели у оквиру многонационалних држава - СССР-а и Југославије. Феномен масовних контаката између два народа настао је усред интензивног и крцатог дешавањима раздобља светских ратова богатог конфликтима идеолошке и војне природе.

Кључне речи: Београд, мостови, руски народ, српски народ
\end{abstract}

Главни град Србије има више мостова изграђених махом у 20 веку. Мостове у Београду су градили и рушили највише сами Срби, али и бројни странци Немци, Данци, Французи, Кинези па и Руси. Најактивнији односи уз масовне контакте српског и руског народа одвијали су се када су Руси и Срби живели у оквиру многонационалних држава - СССР-а и Југославије. Феномен масовних контаката између два народа настао је усред интензивног и крцатог дешавањима раздобља светских ратова богатог конфликтима идеолошке и војне природе. 
У Првом светском рату руски инжењерски одред под командом инжењерског пуковника Доброва се бавио успостављањем и одражавањем прелаза преко река у позадини српске војске, као и припремом понтонског парка за прелаз преко Саве и Дунава. Потреба српске војске за школованим понтоњерима у јесен 1914. је била огромна. Сликовита су сећања команданта Тимочке дивизије, потврђена „исказом команданта мостовог трена и званичним подацима“ о првим данима борби за време преласка Саве у септембру 1914. Радило се о целом сплету околности: место за прелаз командант је одређивао одока по карти без претходног испитивања обале, дна и брзине тока реке; „мост се није могао за кратко време подићи зато што је материјал био апсолутно неупотребљив, понтони су били толико расушени да се нису могли ни на води калофонисати, а неки су били сасвим трули, за постављање моста није пре свега било ни довољно стручних понтоњера, већ су за тај посао употребљавани и коморџије и пионири“. Због тога, мост су за време преласка изградили до пола реке, а после су схватили да недостаје материјала и даља изградња је ишла веома споро. Након преласка, када се указала потреба за хитним повлачењем испоставило се да је мост попуцао, те је био поправљен тек након одређених неприлика. ${ }^{1}$ У овим околностима рад Инжењеријског одреда под командом пуковника Доброва, који је стигао у Србију са групом понтоњера и понтоњерским парком почетком новембра 1914, изгледао је као једна веома битна група стручњака. Значај тог одреда види се из личне молбе председника српске Владе и министра иностраних дела Н. Пашића, српском посланику у Петрограду М. Спалајковићу да испослује долазак друге групе инжењераца у априлу-мају $1915 .{ }^{2}$ Као што се види из докумената у овом

1 „Погибија код Чеврнтије. Поновно суђење ђенералу г. Влад. Кондићу, бившем команданту тимочке дивизије“, Полииичка, бр. 4993, 18. марта 1922.

2 АС, МИД, Пс, П-По, фI, p37/1915 
зборнику, та група је стигла у Србију. Ипак, због повлачења руских трупа из Галиције није уследила српска офанзива према панонској равници, а улога руских инжењераца углавном се огледала у прављењу и одржавању мостова код Ћуприје, што је било значајно током повлачења српске војске у октобру 1915. И мада су руски војници учествовали у одбрани Београда 1914. и 1915. руски артиљерци и минери су учествовали у одбрани Београда, ни они нити руски инжењерци ипак нису добили прилику да дођу у контакт са београдским мостовима ${ }^{3}$.

Први београдски мост чија је историја повезана са Русима је мост Краља Александра који сада многи становници Београда знају као Бранков мост, изграђен 1930-1934. Пилоне за овај мост је пројектовао руски архитекта Николај Краснов, познат као аутор низа репрезентативних зграда у Београду ${ }^{5}$. С друге стране, у раду на изградњи моста је учествовала француска фирма Batignolles, која је као подизвођаче за грубе физичке радове користила услуге руске фирме козачког генерала Андреја Шкуро који је организовао у овом раду више стотина руских емиграната козака. Рад руских војника и официра, који су зарађивали свој хлеб у тешком физичком раду огледао се у подводним радовима и раду на насипу на земунској страни. Насип на земунској страни и масивне камене плоче основа моста који се уздижу усред обилазног саобраћаја на Карађорђевој улици представљају

3 Руска војна йомоћ Србији за време Првої светискоі̄ райа, зборник ірађе, приред. А. Тимофејев, Д. Кремић, Београд, 2014.

4 У. Рајевић, Коњаници за мост краља Александра I у Београду, Гоgиштьк ірpaga Беоіраga 6р. XXXIV, 1987; А. Кадијевић, Историја и архитектура земунског моста Краља Александра I Карађорђевића, Пуиеевима инженерстива у Србији бр., 4, 1996; А. Илијевски, Прилог проучавању архитектуре и идеологије моста витешког краља Александра Првог Ујединитеља у Београду, Наслеђе бр., XIV, 2013.

5 Н. Н.Калинин, А. Кадиевич, М. А. Земляниченко, Архитектор Высочайшего Двора, Симферополь: Бизнес-Информ, 2003. 
једине трагове ових радова заборављених руских емиграната и познатог царског архитекте 6 .

Само неколико дана јуначке борбе за ослобођење града Београда вежу Русе за још један Београдски мост стари Савски мост. Овај мост су Немци изградили за време окупације Београда 1942, да реше проблем кретања преко Саве пошто је мост Краља Александра био срушен.

Значајни број наших суграђана сигурно је чуло за ратног ветерана балканских ратова, и Првог светског рата и учитеља основне школе „Јанко Веселиновић“ на Дорћолу Миладина Зарића (1889-1976). За своју храброст у ратовима Србији у којима је учествовао као резервни официр добио је златни и сребрни Орден за храброст „Милош Обилић“, Крст краља Петра првог и Албанску споменицу. Службовао је као наставник у Ковиљу и у Ужицу, у родном Косјерићу и у Жаркову, пре него што је дошао да ради у сам главни град. М. Зарић је описао своју улогу у спашавању моста након две недеље после догађаја у дневном листу "Политика” на следећи начин „Станујем баш преко пута тог моста, у Карађорђевој 69... Свакога дана ишао сам 5-6 пута, гледао како се Немци пењу и како намештају каблове и мине. Најзад, 20. октобра, чуо сам клицање Руса у Босанској улици. Видео сам у том браћу Русе где долазе од железничке станице. Потрчао сам им у сусрет, наљубио се с њима и позвао их да заједно прегледамо мост... Удаљили су се од моста, јер нису ни имали наређење да пролазе преко њега него да иду за Калемегдан. Казао сам тада да сам бивши српски официр и рекао да ћу ја спасти мост. Да не бих обрукао образ пошао сам сам. Видео сам ужас на мосту. Мноштво ратне спреме и мртвих Немаца. Полако сам се приближавао своду и први пут сам прочитао да на том мосту пише како је то тобоже мост Принца Евгена... изнад табле где је то писало видео сам и бакарне жице, па сам решавао да ли да претрчим и последњих сто метара до плавичастог дима... Ашовом ударио сам по снопу жица, како нисам био задовољан окренуо

6 AJ, Збирка планова Архителтонског одељења Министарства грађевине, Мост краља Александра преко Саве у Београду $(601,676,680)$ 
сам се и узео један крвав немачки тесак. Колико сам пута ударио, не знам. Тек, шиштање је престало, али на одстојању од 20 метара са земунске стране горео је пожар на 3 места. Покушао сам да ашовом угасим, али сам видео да ни 50 људи не би могли да угуше ову ватру... Тада сам се окренуо Русима и махао шеширом. Били су далеко од 200 метара. Договарали су се неко време, да се онда њих 40 попело на мост. Ишао сам с њима све до леве обале. Оној четрдесеторици придружио се цео један батаљон, па су почели да се спуштају у обалобран у Сајмиште. Ту су већ примили борбу са Немцима. Почело је пушкарање. У истоме одсудноме тренутку ураган топовске ватре срушио се на мост. Многи погинули, многи рањени, под је моста испроваљиван али су Руси куљали, оправљали мост и ишли ка Сајмишту превлачећи топове и напредујући даље ка Земуну са НОВЈ..." З За свој подвиг Миладин Зарић је добио југословенски Орден за храброст и совјетски орден. Командант 73. дивизије генерал С. Козак писао је у образложењу награде Отаџбинског рата 1. реда да је „Зарич Миладин Захарович, беспартијни, Србин, добио је контузију у борбама на р. Сави 1944.“, а његов подвиг је био у томе да се он први попео на мост преко р. Саве, и обративши пажњу да је мост миниран пресекао је упаљени штапин и на тај начин је омео детонацију амонала. У закључку је утврђено да „Јуначки подвиг гр. Миладина Зарића имао је одлучујући допринос у обезбеђивању заузимања прелаза преко р. Саве и у обезбеђењу мостобрана на њеној десној обали“. Награду је подржао командант 57. армије генерал-лајтнант Шарохин и сам командант 3. Украјинског фронта Ф. И. Толбухин, али је на интервенцију непознатих инстанција дошло до одбијања у уручивању одликовања за јуначко дело, које је било најзад уручено у облику Ордена Отаџбинског рата 2. реда. ${ }^{8}$

Интересантно је али се скоро истог дана у новинама 57. армије појавио опис другог дела догађаја: 12 совјетских војника и официра из 9. чете 3. батаљона 211. пука 73. гар-

7 Учитељ Миладин Зарић спасао Земунски пешачки мост, Политика, 30. октобра 1944, с. 4.

8 ЦАМО, ф. 33, оп. 686196, д. 6535, с. 2. 
дијске стаљинградске пешадијске дивизије су избили на мост према наредби свог команданта чете старијег лајтнанта Филипа Хохича. Командант јуришне групе је био старији лајтнант Петар Осипов, његов заменик лајтнант Василиј Киселев, млађи лајтнант Иван Камдин, группа пешадије у саставу: заставник Иван Јуносов, водник Иван Боси, водник Владимир Фанајлов, редов Јаков Кучеренко, редов Николај Гришинок, редов Алексеј Белоус, редов Петар Пиштој и редов Каркен Аскаров. Ова јединица је према писању аутора успела да пређе мост и да заузме позиције на земунској страни где је сузбијала покушај да се мост поново минира до доласка основних снага совјетских трупа?.

Отварање Централног архива министарства одбране Русије за цивилне истраживаче омогућило је детаљно расветљавање овог догађаја ${ }^{10}$. У документима о награди постоје молба о награди са звањем највећег совјетског одликовања - Хероја СССР од стране команданта 211. гардијског пешадијског пука, коју је подржао и командант 73. гардијске дивизије, али деградирао до ордена командант 64. корпуса, а на крају дефинитивно одредио наредбом бр. 195/Н од 26.12.1944. командант 57. армије. Официри и подофицири (Ф. Хохич, П. Осипов, И. Камдин, И. Јуносов) су добили Орден црвене завставе (3. у реду између 33. совјетских ордена). Редов К. Аскаров (18. по реду међу 33. совјетска ордена) добио је Орден Отаџбинског рата 1. реда, пошто је спадао у ред националних мањина (Казах). Најзад гардијски војници А.Белоус, И. Боси, Н. Гришинок, В. Фанајлов, J. Кучеренко, П. Пиштој су добили Орден црвене звезде (22. у реду међу 33. совјетска ордена). ${ }^{11}$ Без награде је остао лајтнант В. Киселев, који је већ добио

9 Звезда Совјетов, 1 ноября 1944, с. 2.

10 Осим архивских докумената, које користимо у овом раду истраживачи могу да се упознају са подацима електронских база скенираних докумената о наградама http://podvignaroda.ru; о погинулим http://www.obd-memorial.ru; о бробеним операцијама https://pamyat-naroda.ru.

11 ЦАМО, ф. 33, оп.690306, д.3213, с. 135-200. 
орден Црвене звезде у септембру 1944. за јуначко држање у борби код с. Поганешти (Молдавија) крајем августа 1944.

Документа 73. дивизије имају и друге интересантне податке о старом Савском мосту. Како се то често дешава у борбеним околностима Савски мост, који је добио толику вредност 20. октобра, изгледао је као пожељна мета само неколико дана пре тога. Немци су грчевито бранили мост који је служио за повлачење технике, муниције и људства. Мост су бранили тешки 150 мм топови из Земуна, три самохотке, две батерије 119,6 мм минобацача и две батерије минобацача 81,4 мм. Ова одбрана моста је била повезана са покушајем Немаца да сачувају мост као једини спас за групу, која се пробијала према Сави из правца Авале. Док напредовање ове групе није било заустављено, совјетски атриљерци су покушавали да зауставе кретање по мосту, који нису могли да униште јер нису имали довољно муниције од 152 мм и 122 мм, а гађање са затворених позиција није давало задовољавајуће резултате. На само 900 м од моста на позиције за на директно гађање биле су постављене две хаубице 152 мм и три гаубице 122 мм. Услед тога су морали да подигну 2 топа 45 мм на 1 спрат околних зграда, а у потковље већих зграда које су гледале на реку су ставили неколико 6 ПВО митраљеза ДШК 12,7 мм, што је зауставило кретање Немаца преко моста, али је изазвало појачано гађање немачке артиљерије са друге стране реке ${ }^{12}$. Дивизијски инжењерци су покушавали уништити мост пливајући на гуменом чамцу ca теретом експлозива (50 кг) 16. октобра, али су били приморани на повлачење од моста до ког нису дошли само 50 м снажном ватром непријатеља. Следећег дана, 17. октобра група дивизијских инжењераца учествовала је већ у покушају заузимања моста са групом пешадије али је била приморана на повлачење одлучним контранападом непријатеља и успела је максимално да се приближи мосту на 80 м. Услед свих ових напада дрвена површина моста је била запаљена, а након успешног погодка из 155 мм топа мост се искривио.

12 ЦАМО, Ф. 1212, О.1, Д.42, с. 75-81. 


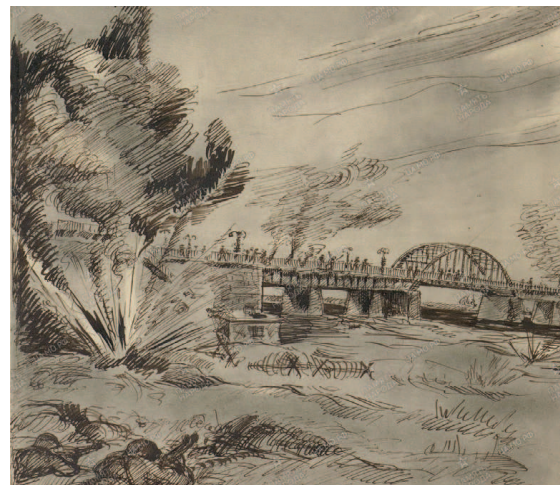

Цртеж припадника 11. бригаде јуришних инжењера „Борба за Стари савски мост“. ${ }^{13}$

У 5.00 ујутро немачке трупе су почеле да се повлаче са десне стране савског мостобрана, што су приметиле јединице 53. јуришног инжењерског батаљона из састава 11. бригаде јуришних инжењера (својеврсног спецназа Црвене армије Другог светског рата који је изводио најтеже операције - на пример у Београду учествовао је у заузимању одбрамбеног чвора хотела Албанија, а касније - Калемегданске тврђаве) ${ }^{14}$. Најзад, у 6.00 ујутро 20. октобра после кратке, али одлучне и интензивне артиљеријске припреме јединице 73. дивизије у сарадњи са снагама 4. механизованог корпуса и борцима НОВЈ успела је да избије код београдске стране моста. Паралелно са јуришем на мост ујутро 20. октобра снаге 509. и 814. пешадијског пука 236. дивизије у сарадњи са тенковима и противтенковским снагама 4. механизованим корпусом и борцима НОВЈ су водили борбе за железничку станицу и Калемегданску тврђаву. Вероватно је припаднике 236. дивизије који су се кретали у правцу Калемегдана је покушавао (неуспешно) да позове на мост

13 ЦАМО, Ф. 30398, О. 1, Д. 44, с. 40.

14 ЦАМО, Ф. 30398, О. 1, Д. 44, с. 39. 
М. Зарић ${ }^{15}$. Према наређењу команданта 73. дивизије на челу офанзиве на мосту су били борци 211. пука. Њима су се придружили и јуришни инжењерци из 53. јуришног инжењерског батаљона који су блокирали ватрене тачке непријатеља у непосредној близини моста на земунској страни и чврсто су заузели одбрану до доласка појачања из састава пешадијских трупа ${ }^{16}$. После успешног продора претходнице на мост дивизијски инжењерци 73. дивизије су под ватром непријатеља скидали противтенковске мине са леве стране мостобрана Савског моста (11 мина T. Mi. 42 код самог моста и 18 мина T.Mi. 43 на даљем путу). Након ступања совјетских војника на мост ватра је око 10.30 била концентрисана на левој страни моста са циљем спречавања немачког контранапада. Осим 152 мм гаубица ову ватру су водили вишецевни бацачи ракета БМ-13 („Каћуше“) и новија модификација крупнијег калибра БМ-31-12 (306 мм). Услед губитка координације ефикасност ватре немачке артиљерија је опала. Од 10.30 до 12.00 немачки топови су направили око 250 пуцња по мосту, али само три 105 мм гранате је пало на сам мост, што је спречило његово даље урушавање. Авиони ИЛ-2 совјетске јуришне авијације су ућуткали немачке топове великог калибра на земунској страни, што је додатно осигурало мостобран. Већ у 11.15 часова 20. октобра с друге стране моста појавио се први совјетски топ, а до 12 часова мостобран су бранила два 45 мм топа и два 76 мм. Такође, на леву страну Саве су прешле и снаге 1. батаљона 214. пешадијског пука 73. дивизије ${ }^{17}$. Инжењерци су онеспособили и експлозив, детонаторе и жице које су ишле у центар за уништење моста смештени у зградама ста-

15 ЦАМО, Ф. 1516, О. 1, Д.11, с. 36-44.

16 ЦАМО, Ф. 33, оп. 690306, д. 2792, с. 309; ЦАМО, Ф. 33565, О. 221670, Д. 3, с. 40.24.

17 ЦАМО, ф. 33, оп. 690306, д. 3213, с. 142, 145. 
рог Сајмишта. ${ }^{18}$ На леву страну Саве прешла је и остала артиљерија 73. дивизије. Снаге 73. дивизије су успеле да сломе немачки покушај да се ликвидира мостобран, који је непријатељ изводио снагама пешадијом ојачаном са неколико тенкова. А већ увече 20. октобра јединице 73. гардијске дивизије којима су се придружиле и снаге 236. дивизије наставиле су офанзиву чији циљ је био потискивање непријатеља ван граница гађања центра града и завршио се 22. октобра 1944. ослобођењем Бежаније ${ }^{19}$.

У ослобођеном Београду још један мост био је повезан са Русима. Када је нова југословенска власт одлучила да започне чишћење и преуређење Београда било је одлучено да се ради на битнијим стварима између којих су били мостови и пре свега мост преко Дунава, изграђени 1935, срушени приликом повлачења 1941, и дефинитивно уништени у савезничком бомбардовању 1944. Значај Панчевачког моста за кретање трупа и терета у стратешком контексту био је очигледан и команди Јужне групе трупа (наследнице 3. Украјинског фронта стациониране у Аустрији, Румунији и Бугарској под командом маршала Ф. И. Толбухина) па и совјетској влади. Совјетске инжењерске јединице су учествовале у градњи моста који је био обновљен и завршен у рекордном року за мање од две године. Јосип Броз Тито је 29. новембра 1946. отворио Панчевачки мост преко Дунава, који је добио назив мост Црвене Армије. Обнова моста је почела после завршетка рата. На челу тима од 50 -ак руских инжењера био је генерал-лајтнант Владимир Александрович Головко. Овај официр био је постављен 1942. за начелника Главне управе ратне војно-реконструкторских радова Народног комесаријата саобраћаја СССР. Током рата његова установа је обновила око 120 хиљада км пруга, 2756 великих и средњих мостова укупне дужине 243.143 метра, више од 13 хиљада малих мостова и цевопровода, 40 тунела и 182 локомотивска депоа. Између тих мостова био је и наш мост у

18 ЦАМО, Ф. 1212, О. 1, Д. 42, с. 67-70.

19 ЦАМО, Ф. 1212, О. 1, Д. 42, с. 75-81. 
Београду. Први воз је прешао мост 7. новембра 1946. године, а возила су кренула преко моста на праздник - 29. новембра 1946. Мост је тог дана отворио сам Јосип Броз Тито који је дао мосту име Мост Црвене Армије. Совјетски и југословенски учесници изградње моста су добили посебно сковану за ову прилику медаљу са натписом „За грађење моста преко Дунава. ФНРЈ 1945-1946. Београд“, сликом моста и амблемом Министарства саобраћаја ФНРЈ осмишљеном по обрасцу совјетског министарства транспорта. У свечаној потврди коју су добијали поводом градње стајао је цитат Тита „Учинимо све да 1946. година буде година великих побједа у обнови“, пуна формулација захвалности „У знак благодарности за Ваш добар рад Министарство Саобраћаја ФНРЈ награђује Вас споменицом 'За грађење моста преко p. Дунава у Београду’. Датум завршетка моста (уручења медаље)“ новембар 1946. и лични потпис првог министра саобраћаја ФНРЈ Тодора Вујасиновића Тоше.

Ипак, данашњи изглед мост је добио нешто касније када је Н. Хрушчов понудио Титу неку помоћ као облик помирења после нормализације 1955. Услед пружања ове помоћи на стратешком за Југославију мосту била је завршена реконструкција старог моста, на месту кога био је фактички изграђен још један мост са два железничка колосека. Радови су на новом мосту били завршени 1956. уз уклањање и делова старог моста. Мост је био додатно прошириван 1960-их година. И остао је у истом стању до скорашње реконструкције 2008-2012.

Од седам мостова у садашњем Београду три моста имају у својој историји чврсте везе са Русима. Ове везе не представају неку доминанту, или чак већину у неком пољу. Вероватно су Немци (ако овде урачунамо и аустријанце) су изградили у Београду највише мостова, мада због њих највише мостова у Београду и пало у воду. Пупинов мост преко Дунава такмичи се по дужини са Панчевачким мостом (бившим мостом Црвене армије), а мост на Ади вероватно надмашује по лепоти све остале 
београдске мостове. У новим реконструкцијама одлазе у прошлост инжењерски радови руских пројектаната раздобља светских ратова. Ипак, лепо је знати да Русима није пошло за руком да сруше ни један мост у Београду. Већ ово пуно значи у историјату односа два народа, које физички спајају дугачке луке Панчевачког моста, снаже нововизантијске пилоне Бранковог моста и чувају поливени брастком крвљу мостобрани Старог савског моста.

Aleksej Timofejev

\section{BRIDGES OF BELGRADE IN THE CONTEXT OF SERBIAN-RUSSIAN RELATIONS IN THE 20TH CENTURY}

\section{Summary}

The capital of Serbia has several bridges that have been built mostly in the 20th century. Bridges in Belgrade were built and destroyed mostly by the Serbs themselves, but also numerous foreigners - Germans, Danes, French, Chinese and Russians. The most active relations in the mass contacts of the Serbian and Russian peoples took place when the Russians and Serbs lived within the multinational states - the USSR (Union of Soviet Socialist Republics) and Yugoslavia. The phenomenon of mass contacts between these two nations was created during a period that was intense and full of events, a period of world wars, rich in conflicts of ideological and military nature.

Key words: Belgrade, bridges, Russian people, Serbian people 